\title{
Sero - Prevalence of Rubella Virus Igm among Pregnant Women Attending Aminu Kano Teaching Hospital Kano, Nigeria
}

\author{
${ }^{1}$ S. Abdulkadir, ${ }^{1} \mathrm{R}$ M kutama, ${ }^{2 *}$ Aminu. A. \\ ${ }^{1}$ Department of Biology \\ Saadatu Rimi College of Education, \\ P.M.B 3218 \\ Kumbotso, Kano state.
}

${ }^{2}$ Nigerian Institute for Trypanosomiasis Research

P.M.B. 2077,

Kano State Liaison office.

Email: halifaone@gmail.com

\begin{abstract}
The 96 well micro-titer plate was first secured in the holder, a data sheet with sample identification was prepared, leaving one well for blank, one hundred micro-liter of negative control was added to the next 3 wells, then $100 \mu \mathrm{L}$ of positive control to the following 2 wells. One hundred micro - liter of the sample diluents was added into each of the test wells which were followed by adding $10 \mu \mathrm{L}$ of specimen into each of the wells containing sample diluents. 300 pregnant women screened for the rubella IgM antibody, a total of 12(4.0\%) were positive, in the young adults category of 15-24 years 88 pregnant women were screened with $5(1.7 \%)$ testing positive. One hundred and forty four were within 25-34 age group with 4(1.3\%) seropositive. Three (1.0\%) of the 68 women in 34-44 age group were positive. The highest prevalence was found in the young adult's category of 15-24 age groups. The research provided an evidence of relatively low prevalence and a high percentage of susceptible population which is an evidence that many in the population are susceptible to rubella virus infection. The findings of an immune response in first trimester of pregnancy indicates $90 \%$ chances of passage to the feotus with serious complications. There is need for awareness creation on rubella virus and congenital rubella syndrome with increase in disease surveillance nationwide. With high level of susceptible population coupled with no immunization policy on rubella in the country underscores the need for initiating organized routine screening and vaccination among healthcare workers, children, adolescents and women of child bearing age as well as ascertaining the potency of vaccines prior to recommendation for vaccination.
\end{abstract}

Keywords: Sero - Prevalence, Rubella Virus, Pregnant Women

\section{INTRODUCTION}

Rubella was first described in the mid-eighteen century by Friedrich Hoffmann who made the first clinical description of rubella in 1740 (Ackerknecht and Erwin, 1982), which was further confirmed by de Bergen in 1752 and then Orlow in 1758 (Wesselheoeft, 1949).

*Author for Correspondence

S. Abdulkadir, R. M. Kutama, Aminu A., DUJOPAS 7 (3b): 115-123 2021 
George de Maton in 1814 was the first to suggest it being considered a disease different from both measles and scarlet fever. The infection was known as Rotheln (Contemporary German Rotelhn), all the physicians being Germans hence the disease was named "German measles" (Best et al., 2005). An English Royal Artillery surgeon Henry Veale described an outbreak in India; he coined the name "rubella" (From Latin, meaning "little red") in 1866. (Lee and Bowden, 2000; Atkinson et al., 2007). Rubella was recognized formally as an individual entity in 1881 at the international congress of medicine in London (Smith, 1881). Alfred Fabian Hess in 1914 theorized that rubella was caused by a virus based on a research he did on monkeys. (Hess, 1914). Hiro and Tosaka in 1938, confirmed the work of Hess by infecting children using filtered nasal washings from acute cases (Atkinson et al., 2007). A wide spread epidemic of rubella was reported in Australia in 1940. An ophthalmologist Norman McAllister Greg found about 78 cases of congenital cataracts in infants where 68 of the cases were born of mothers who had history of rubella in early pregnancy. (Blackmore et al.,2006). In the year $1964-65$, an estimated case of 1.2 million was reported in the United States resulting from a pandemic between 1962 and 1965 starting in Europe which spread to the United States (Blackmore et al., 2006). This resulted to 11,000 miscarriage and 20,000 cases of congenital rubella syndrome (Blackmore et al., 2006).

Rubella virus, a member of the Togaviridae family is the sole member of genus Rubivirus. Its morphological features and physiochemical properties placed it in the togavirus group, the virus is not spread by arthropods (Brooks et al., 2004). The virus is small about $60 \mathrm{~nm}$ in diameter and has a single stranded RNA (Frey, 1994) Rubella virus has a teratogenic property being able to cross the placenta where it interferes with the development of the foetus by either stopping the cells from developing or destroying them. (Edlich et al., 2005). The presence of surface glycoprotein gives the virus an in-vitro heamagglutinating ability inhibited by specific antibody which allows for serological identification of the virus (Edlich et al., 2005). Rubella is usually an infection characterized by a mild self limited disease associated with a characteristic rash (CDC, 2001). The incubation period for rubella is 12-23 days while the infectious period is from seven days before 5-7 days after rash onset. Although rubella is asymptomatic in $25 \%-50 \%$ of cases, some individuals may experience prodromal symptoms such as low grade fever, conjunctivitis, sore throat, coryza, headache or malaise and tender lymphadenopathy. These prodromal symptoms will usually last 1-5 days before the onset of scarlet in form of rash, which may be mildly pruritic. (Edlich et al., 2005). The rash characteristically begins on the face and spreads to the trunk and extremities. It usually resolves within 3 days in the same order in which it appeared. Other manifestations although rare include thrombocytopenia, post infectious encephalitis, myocarditis hepatitis, hemolytic anaemia and hemolytic uremic syndrome. (Bayer et al.,1965). Clinical findings in newborns and virus isolation studies have demonstrated that foetal infection is rare beyond the second trimester of gestation, acquired rubella infection (i.e. not congenital) is transmitted via air borne droplet emitted from the upper respiratory tract of active cases. It may be present in urine, faeces and on the skin with incubation period of 2 - 3 weeks (Richardson et al., 2001).

Rubella is generally a mild illness and serious complications are rare. However, primary maternal rubella virus infection during the first trimester of pregnancy carries a high risk for the development of congenital rubella syndrome (CRS) with characteristic malformation of the heart, eye and ear or even death of the foetus. (Black et al., 1983). The prevalence of rubella immunity differs in different geographical zones of the world, these differences are attributed to immunization policy on rubella in different countries with high immune responses (Black et al, 1983). In Nigeria for instance few studies on rubella infection and available studies indicated $20-60 \%$ of the populace lack rubella immunity, this is in sharp 
contrast to developed countries of Northern Europe and USA where prevalence of immunity was reported to be $95 \%$. (Ukkonem and Borsdonff, 1988). The risk of congenital rubella in sero-negative pregnant women has been found to produce congenital abnormalities. (Bamgboye et al., 2004). A physically or mentally handicapped child becomes a burden to the family as well as the society. Some infections which the mother contracts during pregnancy may cause handicap like- infections caused by rubella virus. (Bale and Murph, 1992). These infections are usually sub- clinical and the affected children may be born apparently well, but subsequently develop the evidence of mental retardation and other disabilities such as deafness and blindness hence the need for antenatal screening. (Remington and Klein,1990). Rubella virus being most consistent in its harmful effects on foetus can be transmitted through the placenta and is capable of causing serious congenital defects, abortion and still birth (Ezike et al., 2003). The risk of foetal infection is about $90 \%$ during the first trimester when the majority of these infants suffer from congenital defects such as total or partial blindness $(78 \%)$, sensorineural hearing loss $(66 \%)$, psychomotor delay $(62 \%)$, mental retardation (42\%) and heart disease $(58 \%)$ are commonly found in infants with congenital rubella virus infection (Givens et al., 1993). There is a $2 \%$ mortality rate among the congenital infected infants who were symptomatic at birth (Katz, 1992). Diagnosis of rubella by clinical evidence may not be reliable and does not give a complete picture of the situation because nearly one half of individual infected with the virus are asymptomatic. (Ezike et al., 2003).

\section{MATERIALS AND METHOD}

Sampling Site: The investigation was carried out at Aminu Kano Teaching Hospital (AKTH), the hospital is located in Tarauni local government area in the locality of Unguwa Uku within the city of Kano State, geographically the area lies within the latitude of $11^{0} 57$, $31^{\circ} \mathrm{N}$, and $8^{0} 32^{\mathrm{I}} 39,4^{\circ} \mathrm{N}$ Kano.

Sample Size: This was calculated using the standard epidemiological statistical software (Open Epi version 2.2). Prevalence rate of $7.1 \%$ of rubella virus infection was adopted as reference prevalence at 5\% confidence level (Yahya et al., 2015).The sample size was calculated as 221 which was rounded up to 300 to cover experimental errors.

\section{Rubella virus IgM antibody detection.}

This was carried out using ELISA (Enzyme - Linked Immunosorbent Assay) antibody detection technique using commercially IgM and IgG ELISA kit(Axiom diagnostics, Germany with code number 881432) according to the manufacturers instruction.

\section{Reagent Preparation}

The assay reagents were removed from the fridge and allowed to acclimatize at room temperature after which the bottles were swirled gently to ensure thorough mixing. The wash fluid was diluted 20 folds with distilled water. The dilution was achieved by adding $950 \mathrm{ml}$ distilled water to $50 \mathrm{ml}$ of the wash fluid concentrate provided, the incubator was calibrated at $37^{\circ} \mathrm{C}$ and the reagents were then transferred into different disposable troughs. This was achieved according to manufacturers instruction.

\section{Assay Procedure}

The assay procedure was achieved using the manufacturer's instructions.

The 96 well micro-titer plate was first secured in the holder, a data sheet with sample identification was prepared, leaving one well for blank, one hundred micro- liter of negative control was added to the next 3 wells, then $100 \mu \mathrm{L}$ of positive control to the following 2 wells. One hundred micro - liter of the sample diluents was added into each of the test wells 
which was followed by adding $10 \mu \mathrm{L}$ of specimen into each of the wells containing sample diluents. The mixture was vortexed for 10s. The plate seal was applied and incubated for $45 \mathrm{mins}$ at $37^{\circ} \mathrm{C}$. After incubation the plate was washed six times using an automated microplate strip washer, stricken on an absorbent paper at the end of the last wash cycle. One hundred micro-Liter of enzyme conjugate reagent was added into each of the wells except the blank well, mixed on a vortex mixer, covered and incubated at $37^{\circ} \mathrm{C}$ for $45 \mathrm{mins}$. At the end of incubation period, the plate was washed in an automated micro-plate strip washer, stricken on an absorbent paper after the end of the last wash cycle. One hundred micro-Liter of enzyme conjugate was added into the wells, except blank. $50 \mu \mathrm{L}$ micro-liter of the substrate solution and $50 \mu \mathrm{L}$ of the chromogen solution was added into each of the wells. This was gently mixed on a vortex mixer and incubated at $37{ }^{\circ} \mathrm{C}$ for $10 /$ minutes in a dark place. This was achieved by inserting the plate in a dark drawer. At the end of the incubation period $50 \mu \mathrm{L}$ of the stop solution was added into each of the wells and mixed thoroughly on a vortex mixer. The absorbance was read at $450 \mathrm{~nm}$ using $620-630 \mathrm{~nm}$ as the reference wavelength.

The test was recorded as valid when the absorbance of positive control $\geq 0.7$ and that of negative control $\leq 0.1$. The cut off value was calculated thus: Cut off Value $=0.1+$ mean absorbance of negative control.

0.05 was used instead of the actual mean in cases where the mean absorbance of the negative replicates 0.05 . The specimen was interpreted as positive when the absorbance $\geq$ cut off value, however if was lower than the cut off value it was interpreted as negative as outlined by the kit's manufacturer.

\section{Statistical Analysis}

Chi-square was used to determine the relationship between socio-demographic factors and rubella positivity.

\section{RESULTS}

\section{Table 1: Sero -prevalence of Rubella IgM among Pregnant Women in Kano}

Table one represent the sero-prevelence of rubella immunoglobolum $\mathrm{M}$ among pregnant women in kano state showing women within the age group of 15-24 has the higest prevalence with total number of 88 and 1.7\% while age group 35-44 has total number 68 and $1.0 \%$ was the least prevalence.

\begin{tabular}{lll}
\hline Age & Total & Total Positives (\%) \\
\hline $15-24$ & 88 & $5(1.7)$ \\
$25-34$ & 144 & $4(1.3)$ \\
$35-44$ & 68 & $3(1.0)$ \\
\hline Total & 300 & $\mathbf{1 2 ( 4 . 0 )}$ \\
\hline
\end{tabular}

Table 2: Sero-prevalence of Rubella IgM Based on Socio-demographic Factors

Table two below indicated the socio-demographic factors of sero-prevalence of rubella immunoglobulin $\mathrm{M}$, the age group of 15-24 has the highest positive cases of 5 women with $1.7 \%$ while the age group of 35-44 has the lowest prevalence cases of 3 women with $1.0 \%$. 


\begin{tabular}{|c|c|c|c|c|c|}
\hline \multicolumn{6}{|c|}{ Rubella IgM antibody } \\
\hline Ages & Positive (\%) & Negative (\%) & Total (\%) & $\mathrm{X}^{2}$ & P Value \\
\hline $15-24$ & $5(1.7)$ & $83(27.6)$ & $88(29.3)$ & 2.230 & 0.526 \\
\hline $25-34$ & $4(1.3)$ & $140(46.7)$ & $144(48.0)$ & & \\
\hline $35-44$ & $3(1.0)$ & $65(21.7)$ & $68(22.7)$ & & \\
\hline Total & $12(4.0)$ & $288(96.0)$ & $300(100)$ & & \\
\hline \multicolumn{6}{|l|}{ Employment } \\
\hline Employed & $6(2.0)$ & $74(24.7)$ & $80(26.7)$ & 3.487 & 0.175 \\
\hline Unemployed & $5(1.7)$ & $17(58.3)$ & $180(58.3)$ & & \\
\hline Self & $1(0.3)$ & $39(13.0)$ & $40(13.3)$ & & \\
\hline \multicolumn{6}{|l|}{ Employed } \\
\hline Total & $12(4.0)$ & $288(96.0)$ & $300(100)$ & & \\
\hline \multicolumn{6}{|l|}{ Education } \\
\hline Primary & $0(0.0)$ & $6(2.0)$ & $6(2.0)$ & 3.425 & 0.489 \\
\hline Secondary & $1(0.3)$ & $79(26.3)$ & $80(26.7)$ & & \\
\hline Tertiary & $11(3.7)$ & $191(63.7)$ & $202(67.3)$ & & \\
\hline None & $0(0.0)$ & $12(4.0)$ & $12(4.0)$ & & \\
\hline Total & $12(4.0)$ & $288(96.0)$ & $300(100)$ & & \\
\hline \multicolumn{6}{|c|}{ Immunization history } \\
\hline Yes & $10(3.3)$ & $238(79.3)$ & $248(82.7)$ & 0.004 & 0.950 \\
\hline No & $2(3.8)$ & $50(96.2)$ & $52(17.3)$ & & \\
\hline Total & $12(4.0)$ & $288(96.0)$ & $300(100)$ & & \\
\hline \multicolumn{6}{|l|}{ Gestational Age } \\
\hline $1^{\text {st }}$ Trimester & $2(0.7)$ & $12(4.0)$ & $14(4.7)$ & 4.050 & 0.132 \\
\hline \multicolumn{6}{|c|}{ Rubella IgM antibody } \\
\hline $\begin{array}{l}\text { Gestational } \\
\text { age }\end{array}$ & Positive(\%) & Negative(\%) & Total $(\%)$ & $\mathrm{X}^{2}$ & P.Value \\
\hline $2^{\text {nd }}$ Trimester & $5(1.7)$ & $141(47.0)$ & $146(48.7)$ & & \\
\hline $3^{\text {rd }}$ Trimester & $5(1.7)$ & $135(45.0)$ & $140(46.7)$ & & \\
\hline Total & $12(4.0)$ & $288(96.0)$ & $300(100)$ & & \\
\hline \multicolumn{6}{|c|}{ History of Miscarriage } \\
\hline Yes & $4(1.3)$ & $108(36.0)$ & $112(37.3)$ & 0.085 & 0.770 \\
\hline No & $8(2.7)$ & $180(60.0)$ & $188(62.7)$ & & \\
\hline Total & $12(4.0)$ & $288(96.0)$ & $300(100)$ & & \\
\hline \multicolumn{6}{|c|}{ History of Still Birth } \\
\hline Yes & $1(0.3)$ & $33(11.0)$ & $34(11.3)$ & 0.112 & 0.738 \\
\hline No & $11(3.7)$ & $255(85.0)$ & $266(88.7)$ & & \\
\hline Total & $12(4.0)$ & $288(96.0)$ & $300(100)$ & & \\
\hline \multicolumn{6}{|l|}{$\begin{array}{l}\text { Knowledge } \\
\text { of rubella }\end{array}$} \\
\hline Yes & $1(0.3)$ & $5(1.7)$ & $6(2.0)$ & 2.558 & 0.110 \\
\hline No & $11(3.7)$ & $283(94.3)$ & $294(98.0)$ & & \\
\hline Total & $12(4.0)$ & $288(96.0)$ & $300(100)$ & & \\
\hline
\end{tabular}

From table 1300 pregnant women were screened for the rubella $\operatorname{IgM}$ antibody, a total of $12(4.0 \%)$ were positive. In the young adults category of 15-24 years 88 pregnant women were screened with $5(1.7 \%)$ testing positive. One hundred and forty four were within 25-34 age group with $4(1.3 \%)$ seropositive. Three $(1.0 \%)$ of the 68 women in $34-44$ age group were positive. The highest prevalence was found in the young adult's category of 15-24 age groups.In table 2 the demographic characteristics of the pregnant women was taken into consideration where it was found out that pregnant women with some level of literacy had the highest prevalence when compared with those with no educational background. The 
highest prevalence was found among those with tertiary level of education at $11(3.7 \%)$.A low prevalence of $1(0.3 \%)$ was found in self employed pregnant women with highest prevalence found in employed pregnant women. Pregnant women with immunization history recorded a prevalence of $10(3.3 \%)$ while those in the first trimester of pregnancy had the least number of seropositive cases at $2(0.7 \%)$. A relative number $8(2.7 \%)$ of the pregnant women with no history of miscarriage was recorded. Out of the 266 pregnant women with no history of still birth, 11(3.7\%) were positive for the rubella IgM antibody while those without previous neonatal death had the least count $1(0.3 \%)$.

\section{DISCUSSION}

Rubella virus is known to cause infection in-vitro and is often responsible for abortion, still births, premature delivery and congenital malformations. There is considerable variable in the prevalence of the virus among women of child bearing age in different geographical locations of the world. (Usher et al., 2004). When a woman is infected with the rubella virus early in pregnancy, she has a $90 \%$ chance of passing the virus onto her fetus and this can cause death of the foetus or may cause congenital rubella syndrome (CRS). In this present study $4.0 \%$ of the pregnant women studied had a detectable IgM level which is a marker of recent rubella infection. Detection of rubella IgM antibody is well established as a means of diagnosing recent rubella / congenital rubella syndrome and is the recommended procedure by the World Health Organization as the primary test for the laboratory confirmation of rubella. Although a major section of pregnant women are believed to be immune to rubella infection, the result of this study shows that cases of rubella infection still exists in Nigeria among pregnant women. (Otaigbe et al.,2006). Results obtained from this study indicated that $12(4.0 \%)$ out of the 300 pregnant women screened were positive for the rubella virus IgM while $288(96.0 \%)$ were negative thus indicating that they lacked specific antibody. Thus indicating that $4.0 \%$ of the study population could be recently infected with rubella virus as the IgM antibody is the body's first line of defense against an antigen which is found in blood and lymph fluids. This corroborates findings of Cutts et al.,(2000) where they reported that the prevalence of rubella virus IgM was less than $10 \%$ but was different from that reported by WHO which placed the worldwide prevalence rate of rubella susceptibility between 7.5-17.4\%. (Dykewicz et al.,2001). The findings also differed from that reported by Yahya et al.,(2015) who reported a prevalence rate of 7.9\%. However the prevalence rate of rubella IgM was found to be lower than $17.4 \%$ reported by Koki et al.,2014 , $6.8 \%$ by Ogbonanya et al.,2012, and $0.2 \%$ by Tamer et al.,2004. Immunization policies among different countries also can play a role in the difference in prevalence rate between two countries as it is in the case of Kishore et al.,(2003) and Yasodhara et al.,(2001) where a higher prevalence of $10.38 \%$ and $6.5 \%$ respectively was reported.

Prevalence based on age group showed pregnant women in the 15-24 age group having the highest prevalence of $5(1.7 \%)$ with the least being in the $35-44$ age group. This finding contradicts that reported by Ogbonanya et al.,(2012) where the highest was found within 2534 age group while at the same time corresponding with reports by Forbi et.,al(2009), this could be due to the fact that rubella virus infection is found more in young adults than older ones although findings were not statistically significant.

$\operatorname{IgM}$ antibodies were found in all trimesters of pregnancy with 5(1.7\%) in the third trimester of pregnancy which was higher than $(0.7 \%)$ in the first trimester. The findings of an immune response in the third trimester of pregnancy corresponds with that reported by Yahya et al.,(2015) but in contrast with that reported by Bamgboye et al.,(2004) and Fokunang et al.,(2010) where their findings indicated the highest prevalence among pregnant women in the third trimester of pregnancy with increased chances of transmission to the feotus, this 
could be attributed to the fact that rubella virus exhibits its manifestation more in the first trimester and antibody diminishes as pregnancy level progresses.

All pregnant women with some level of education were reactive with most susceptible group being those with tertiary education which usually belong to the young adult's category and rubella virus is believed to affect younger women than those in the late thirties or forties. Unemployed pregnant women represented the most susceptible to the rubella virus infection rather than their employed counterparts that mingle with a lot of people of different backgrounds increasing their risk of infection. Immunized and non- immunized pregnant women were also found to be reactive to the rubella virus IgM contrary to that reported by Yahya et al.,(2015) where no case was recorded in non immunized pregnant women, the detection of an immune response in immunized pregnant women could be as a result of substandard vaccines found in our health care facilities or due to the stigma associated with immunization as the pregnant women might give a wrong information for fear of been forced to be immunized. Rubella virus is known to exhibit teratogenic property i.e the ability to cause miscarriage. The present study detected an immune response in pregnant women without previous miscarriages although considered statistically not significant.

\section{CONCLUSION}

The research provided an evidence of relatively low prevalence and a high percentage of susceptible population which is an evidence that many in the population are susceptible to rubella virus infection. The findings of an immune response in first trimester of pregnancy indicates $90 \%$ chances of passage to the feotus with serious complications. Also rubella virus infection was found to be independent of sociodemographic factors at $p>0.05$ in all cases.

\section{RECOMMENDATIONS}

There is need for awareness creation on rubella virus and congenital rubella syndrome with increase in disease surveillance nationwide. With high level of susceptible population coupled with no immunization policy on rubella in the country underscores the need for initiating organized routine screening and vaccination among healthcare workers, children, adolescents and women of child bearing age as well as ascertaining the potency of vaccines prior to recommendation for vaccination. There is also the need for incorporating rubella virus screening in the routine antenatal screenings for pregnant women.

\section{REFERENCES}

Ackerknec H.T and Erwin H. (1982).A short history of medicine.Baltimore, M D: John Hopkins University Press. Pp.129.

Atkinson.W.Hamborsky J. Mcllntyre.L. and Wolfe S.(2007).Chapter 12.Rubella .Epidemiology and prevention of vaccine- preventable disease.10 ${ }^{\text {th }}$ Edition. (Centre for disease control and prevention).

Bale JF andMurph JR.(1992): Congenital infections and the nervous system pediatric clinic of North America Journal of American medical association.39 : 669-690.

Bamgboye A.E., Afolabi K.A., Esumah, F.I. and Erwean., I.B. (2004) prevalence of Rubella antibody in pregnant women in Ibadan, Nigeria.West African Journal. Medicine;23(3):245-8.

Bayer W.L.,M.D., Frank E. Sherman, M.D., Richard H.M., Issabel L.F. Szeto R.T and Jessica H.L (1965). New England journal of medicine. 273:1362-1366. 
Best, J. M. Cooray, S., Banatvala J. E. (2005). Rubella . Topley and Wilson's Microbiology and Microbial Infections, 2. (45) : 960-92.

Black N.A, Persons A, Kurtz JB (1983) .Post partum rubella immunization; a controlled trial of two vaccines. Lancet 2 (8357): 990-2.

Blackmore Tim, Buchan Glenn, Grant Cameron,Grimwood Keith, Lennon D., Mudroch D.,Pierce J., Reid S.,Roberts A.(2006). Ministry of health, immunization handbook, Wellington, New Zealand. P. 41.

Brooks, G.F.; Carroll, K.C.; Butel, J.S. and Morse, S.A.(2004). Paramyxoviruses and rubella virus.In: Medical Microbiology. 24th. Ed.. McGraw-Hill. 546-566

Centre for Disease control (2001). Control and prevention of rubella evaluation and management of suspected outbreaks, rubella in pregnant women and surveillance for congenital rubella syndrome.MMWR July 13,50 (RR 12):1-23.

Cutts R.F,Robertson S.E. and Diaz-Ortega J.L.(2000). Control of congenital rubella syndrome in developing syndrome in developing countries. Part 1: burden of disease from CRS. Bull World Health Organization Organization. 75: 55-80.

Dykewicz, C.A., Kruszon-Moran D. and McQuillan G.M.,(2001) Rubella Seropositivity in the United States, Clinical Infectious Disease. 33: 1279- 1286.

Edlich, R. F.,Winters K.L,Long, W. B and Gubler K.D. (2005)."Rubella and Congenital rubella (German measles)".J. Long term EFF. med. Implants 15(3):319-28.

Ezike.,Ang.J.Y.,A. Smar B.Rubella in Krilov L.R.,WindleL.M.,Barton L.L.,TolanR.W.,Steele R.(2003). E.medicine.P. 1- 4.

Fokunang C.N, Chia J., Ndumbe P., Mbu P., Atashili J.(2010). Clinical studies on seroprvalence of rubella virus in pregnant wome of Cameroon regions. African journal of clinical and experimental microbiology.15(3):151-157.

Frey T.K.(1994). Molecular Biology of Rubella virus. Advanced virus research.44:69-160.

Givens K, Lee D.A., Jones T. Histrup D.M.(1993).Congenital rubella syndrome: Ophthalmic manifestations and associated systemic disorders.358-363.

Hess Fabian Alfred. (1914) .German measles (rubella): An experimental study. The Archives of internal medicine.13:913-916.

Katz S. H. (1992). Rubella (German measles) in Joklikhok. Willet HP Amos D B, Wilfert C.M. Zinser Microbiology 20th ed. California: Appelton\&Lange :Pp, 1016-1018

Kishore, K., Aggrawal J.,Aggrawal S.,Ayyagari A.(2003). Sera analysis of C.trachomatis, and STORCH agents in women with recurrent spontaneous abortions. Indian Journal of pathology and microbiology 46(4):654-87.

Koki A.Y. Mukhtar M.D. and Taura D.W. (2014). Seroprevalence of rubella virus IgM antibodies among pregnant women attending Muhammadu Abdullahi Wase specialist hospital Kano. Communications in applied sciences; 2(1): 141-148.

Lee J. Y., and Bowden D. S. (2000). Rubella virus replication and links to teratogenicity. Clinical Microbial Review 3 (14): 571 - 87.

Ogbonanya J.U, Chiwuze J. and Yashdora J.K. (2012). Seroprevalence survey of rubella infection in pregnancy at the university of Benin teaching hospital, Benin city, Nigeria. Nigerian journal of clinical practice.14(2):140-145.

Otaigbe, B.E., Brown, T. and Esu R., (2006). Confirmed Congenital RubellaSyndromeA case report.Niger Journal of Medicine 15(4):448-50.

Remington J.S and Klein J.O(1990). Infectious Diseases of the Fetus and newborn infant $3^{\text {rd }}$ edition.Philadelphia W.B Saunders company.Pp 87-195.

Richardson M., Elliman D., Maguiwe H., Simpson J.,Nicolle A.(2001).Evidence base of incubation periods, periods of infectiousness and exclusion policies for the control of communicable disease in schools and pre-schools .Pediatric infectious disease journal.20(4):380-91. 
Smith J.L.,(1881).Contributions to the study of Rotheln. Transition International, Medical Congressl.4(14).

Tamer G.S. Devrum D. Eray Caliskan (2004). Seroprevalence of Toxoplasma gondii, rubella and cytomegalo virus among pregnant women in western region of Turkey.Clinical and invesigative Medicine. 32 (1): 43-47.

Ukkonem P. and Borsdonff. H.(1988). Rubella immunity and mortality.Effect of vaccination in Finland.Scard journal of infectious diseases.20:255-259.

Usher, A., Shashi, C., and Aruna, A., (2004). Prevalence of IgM Antibodies to Toxoplasma, Rubella and Cytomegalovirus infections during pregnancy. JK science, 6(4):190-2.

Wesselhoeft C.,(1949). Rubella and congenital deformities. New England journal of medicine.240(7):258-61.

Yahya H., Ibrahim A.,Muhammad A.B.,and Dandawaki S.M. (2015). Sero-prevalence survey of rubella IgM antibodies among pregnant women in Kano, Nigeria. International journal of life science and engineering.1(2):56-60.

Yasodhara P.,B.A.,Ramalakshmi, A.N.,Naidu, L. Rahman(2001).Prevalence of specific IgM due to toxoplasma, rubella, $\mathrm{CMV}$, and $\mathrm{C}$. trachomatis infections during pregnancy. Journal of medical microbiology 19(2):52-56. 